\title{
Cover cropping system and mulching can shape soil microbial status in fruit orchards
}

\author{
Andre Freire Cruz $^{1 *}{ }^{*}$, Marcio de Carvalho Pires ${ }^{2}$, Lennon Kaique Beda do Nascimento ${ }^{2}$, Maria Lucrecia Gerosa Ramos ${ }^{2}$,

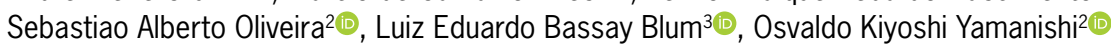

\author{
${ }^{1}$ Kyoto Prefectural University/Graduate School of Life and \\ Environmental Sciences, 1-5 Shimogamohangi-cho - 606- \\ 8522 - Kyoto - Japan. \\ 2Universidade de Brasília/Faculdade de Agronomia e \\ Medicina Veterinária, C.P. 4508 - 70910-970 - Brasília, \\ DF - Brasil. \\ 3Universidade de Brasília - Depto. de Fitopatologia, Campus \\ Universitário Darcy Ribeiro, - 70910-900 - Brasília, DF - \\ Brasil. \\ *Corresponding author <andre@kpu.ac.jp>
}

Edited by: Fernando Dini Andreote

Received September 27, 2018

Accepted January 26, 2019
ABSTRACT: The use of cover crop in agricultural fields has been well elucidated, especially regarding nitrogen fixation from legume crops and their function as weed protection. Furthermore, to cover crops can benefit the soil microbial community. This study aimed to evaluate and compare the benefits of mulching and cover cropping systems on soil microbial growth and activity, and their effects on plant mineral nutrition in pomelo (Citrus maxima) and macadamia (Macadamia integrifolia) orchards. The treatments included: 1) control [Glyphosate herbicide (Roundup at 4 I per ha)], 2) manual weed control, 3) mulching with dead leaves from their respective trees (macadamia and pomelo), 4) millet, 5) faba bean, 6) millet + faba bean. All the treatments were applied for 120 days before soil and plant leaves were sampled for analyses. Plant mineral nutrition, soil microbial biomass $\mathrm{C}(\mathrm{MBC})$ and soil microbial biomass $\mathrm{N}(\mathrm{MBN})$; basal respiration (BRA), arbuscular mycorrhizal fungi (AMF) colonization (COL); number of AMF spores (SPO) in soil; total organic carbon (TOC) and total nitrogen (TN) were evaluated. Plant nutrition was not altered by the treatments; however, the MBC, COL and SPO markedly increased in response to mulching and faba bean + millet treatments. Especially in macadamia soils, these treatments had a great response to soil microbiology. Significant negative correlations were also detected for the COL, SPO, BRA and TOC with the Nutrient Balance Index (NBI). These results indicate that in short-term the cover cropping system is useful to improve the soil microbial growth and AMF formation in soils of pomelo and macadam orchards.

Keywords: pomelo, faba bean, macadamia, millet, mycorrhiza

\section{Introduction}

Macadamia (Macadamia integrifolia Maiden \& Betche) and pomelo (Citrus maxima [Burm.)] Merr.) are produced worldwide, and their edible fruits are used for juice and culinary condiments. In Brazil, macadamia production reached $2845 \mathrm{t}$ in 2014 and pomelo 78491 ton, where the country represents the $16^{\text {th }}$ and $36^{\text {th }}$ producer worldwide, respectively (FAO, 2013).

Cover crops are well known to support soil microbial growth, microbial activity, and plant metabolism, directly affecting soil respiration and plant mineral nutrition (Setyawan et al., 2011), offering great benefits to soil and plants. Their efficiency depends on the weather, plant species, and season. One example is grass, which is appropriate and plays an important role in soil management in citrus orchards, where Bahia grass roots could release stimulatory compounds for arbuscular mycorrhizal fungi (AMF), a beneficial microorganism for plant development (Cruz et al., 2003; 2000).

Legumes represent another type of cover crop, which are more efficient for nitrogen $(\mathrm{N})$ fixation, essential for plant synthesis of protein and production. These cover crops increase soil organic matter (SOM) content, microbial activity, and decrease erosion and incidence of pests and diseases (Zaccheo et al., 2013). However, it is not clear whether a mixed grass and legume cover crop in fruit orchards positively affects soil quality and improves plant production.

Among the legume plants, faba bean (Vicia faba L.) production has increased due to its properties linked to high yield, protein and similar inputs to field pea (Strydhorst et al., 2008). The millet acts as an excellent cover to crop, due to its tolerance to heat and drought (JaymeOliveira et al., 2017). Foxtail (Setaria italica L. Beauv.), proso (Panicum miliaceum L.) and japanese millets (Echinochloa frumentaceae L.) are recommended for summer plantings, because they produce little biomass as a response to longer day-length.

Herbicides have been widely applied for the weed control due to their efficiency. However, these chemicals might negatively affect the soil microbial community, especially biomass and diversity (Subhani et al., 2000). The leaching of glyphosate could change the earthworms and mycorrhizal in soils (Zaller et al., 2014). One efficient alternative for weed control is the mulching with dead leaves, which may add organic matter to soils and stimulate microbial growth and activity (Pimentel and Guerra, 2011).

Therefore, the hypothesis of this work is cover crops intercropped with macadamia and pomelo orchards improve soil microbial biomass and mycorrhizal colonization and sporulation. Thus, we assessed and compared the benefits of cover crop systems and dead leaves mulching on soil microbial growth and AMF formation (colonization and sporulation) and evaluated their effects on plant mineral nutrition in macadamia and pomelo orchards.

\section{Materials and Methods}

\section{Field experiment}

The study was conducted in 2013 in Brasília, Distrito Federal, Brazil $\left(15^{\circ} 44^{\prime} 07.59^{\prime \prime} \mathrm{S}\right.$ and $47^{\circ} 52^{\prime} 56.75^{\prime \prime}$ 
$\mathrm{W}_{\text {; }}$ altitude $\left.1009 \mathrm{~m}\right)$. The weather was defined by two distinct seasons, wet and dry, and more details about local weather are described in Table 1 . The experimental station contained fruit trees separated into plots with different species. The experimental area from which leaf and soil samples were taken contained two orchards of pomelo and macadamia with 20 trees each. Both fruit orchards were 10 years old conducted with conventional methods for weed (herbicide application), pest and diseases (chemical pesticides) control and soil fertility (chemical fertilizers - N-P-K). Productivity was $25 \mathrm{t} \mathrm{ha}^{-1}$ and $10 \mathrm{t} \mathrm{ha}^{-1}$ for pomelo and macadamia, respectively.

Seeds of millet (Pennisetum glaucum [L.] R. Br.) and faba bean (Vicia faba L.) were sown in early July 2013, intercropped with macadamia and pomelo trees, as single treatments or in combination. Millet seeds $\left(25 \mathrm{~m}^{-2}\right)$ and faba bean seeds $\left(22 \mathrm{~m}^{-2}\right)$ were sown for single treatments, and millet $\left(15 \mathrm{~m}^{-2}\right)+$ faba bean $\left(13 \mathrm{~m}^{-2}\right)$ seeds were applied in the mixed plot. The treatments were set as follows: 1) control [Glyphosate herbicide (Roundup at 4 l per ha)], 2) manual weed control, 3) mulching with dead leaves from their respective trees (macadamia and pomelo), 4) millet, 5) faba bean, 6) millet + faba bean. The mulching treatment was the positive control that could be efficient as $\mathrm{C}$ input to soil and block the light penetration to prevent weed growth. The irrigation system was set using black plastic pipes with small holes and was applied for $1 \mathrm{~h}$ per day for 2 months.

\section{Field sampling and analysis}

Sets of four plants from each treatment were chosen for sampling 120 days after cover crops were sown. Four single soil cores were randomly taken for each treatment, in the middle of tree canopy at depth of $10 \mathrm{~cm}$. Samples were then sieved $(2 \mathrm{~mm})$, placed into plastic bags and stored at $4{ }^{\circ} \mathrm{C}$. The microbial biomass carbon (MBC) and microbial biomass nitrogen (MBN) were determined by the fumigation-extraction method (Vance et al., 1987), whereas basal respiration (BRA) of soil was quantified

Table 1 - Monthly average temperature maximum (Tmax), temperature minumum (Tmin), relative humidity $(\mathrm{RH})$ and total rainfall $(\mathrm{mm})$ in 2013.

\begin{tabular}{|c|c|c|c|c|c|}
\hline Month & Tmax & Tmin & $\mathrm{RH}$ & Rainfall & Season wetness \\
\hline & $Z^{\circ}$ & 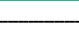 & $\%$ & $\mathrm{~mm}$ & \\
\hline January & 30 & 15 & 80.4 & 518 & Wet \\
\hline February & 31 & 16 & 67.3 & 201 & Wet \\
\hline March & 32 & 16 & 75 & 192 & Wet \\
\hline April & 28 & 15 & 71.8 & 103 & Wet \\
\hline May & 27.5 & 12.5 & 60.4 & 20.5 & Dry \\
\hline June & 27.5 & 11 & 67.5 & 6.5 & Dry \\
\hline July & 30 & 11 & 51.5 & 0.30 & Dry \\
\hline August & 32 & 12 & 69 & 0 & Dry \\
\hline September & 32 & 15 & 50 & 64 & Dry/Wet \\
\hline October & 32 & 14 & 65.7 & 105 & Wet \\
\hline November & 16 & 30 & 72.8 & 199.5 & Wet \\
\hline December & 16.5 & 30 & 78.5 & 339 & Wet \\
\hline
\end{tabular}

by the alkali absorption method through $\mathrm{CO}_{2}$ evolution (Haney et al., 2008). The total organic carbon (TOC) was analyzed by a total organic carbon analyzer and total nitrogen (TN) was determined by the Kjeldahl method. The mycorrhiza colonization (COL) was analyzed by staining with trypan blue and observation in microscope and number of spores (SPO) in the soil was determined by sieving and separation with $50 \%$ glucose (Cruz et al., 2000).

\section{Sampling leaves}

Four trees were randomly selected from each treatment and the leaves were collected from the middle branch between the trunk and canopy top. Approximately 10 leaves were washed, air dried for four days, and then dried again at $65{ }^{\circ} \mathrm{C}$ for two days. The samples were sent to Mycellium Laboratory, Barretos, Brazil, for analysis of macro and micronutrients by colorimetry after digestion (Rengel, 1999). Leaf tissues were analyzed according to methods described previously (Malavolta et al., 1997).

Concentrations of nutrients $\mathrm{N}, \mathrm{P}, \mathrm{K}, \mathrm{Ca}, \mathrm{Mg}, \mathrm{S}, \mathrm{B}$, $\mathrm{Cu}, \mathrm{Fe}, \mathrm{Mn}$, and $\mathrm{Zn}$ in leaves were determined and expressed as grams per kilogram for macronutrients and milligram per kilogram for micronutrients. These data were used for diagnosis and recommendation integrated system (DRIS) application (Lana et al., 2010). The DRIS rates obtained from macadamia and pomelo samples were calculated using computer software (Lana et al., 2010; Oliveira, 2002). By definition, DRIS indices are expressed by positive or negative values, which indicate nutrient excess or deficiency, respectively, thus a value close to zero indicates an adequate nutrient balance (Mourão Filho, 2004). Moreover, the correlation matrix between the nutrients were calculated (Oliveira, 2002).

\section{Statistical design}

The experiment was a complete randomized design composed of six treatments and two species of fruits trees. Four trees were selected for each treatment (representing 4 replicates), totaling 48 experimental units. For the statistical analysis ANOVA was performed with the SISVAR /http://www.dex.ufla.br/ danielff/programas/sisvar.html), and Principal Component Analysis (PCA) and Pearson correlations using the PAST package (https:/folk.uio.no/ohammer/past/). After ANOVA, the means were compared by the Tukey test $(p \leq 0.05)$.

\section{Results}

\section{Microbial growth and activity}

Among the six treatments for macadamia and pomelo, it was evident that cover crops improved microbial growth and activity, especially when used in combination (faba bean + millet). The analysis of variance indicated the significant effect of treatments $(F<0.01)$ for most variables evaluated, except for TN and NBI in macadamia soils and MBN in pomelo soils (Table 2). In macadamia, faba bean + millet increased SPO. Additionally, 
the two cover crops and their combination led to similar responses in pomelo (Figure 1A). Furthermore, the effects of herbicide, manual mulching with dead leaf, and millet treatments differed depending on the fruit orchard. For macadamia, manual and mulching treatments generated a similar value for SPO (Figure 1A).

The COL was increased efficiently in both orchards with faba bean or its combination with millet (Figure 1B). Although the cover crops improved COL and SPO values, they showed different responses for soil respiration (Figure 2A). Only faba beans and faba bean + millet improved BRA in macadamia, compared to manual weed control and control and, in general, no significant differences were found for pomelo; however, a decrease was observed in herbicide treatments for both

Table 2 - Significance of the analysis of variance (ANOVA) of the treatments in macadamia and pomelo experiments [AMF sporulation (SPO), and colonization (COL); Soil Microbial Biomass $\mathrm{N}(\mathrm{MBN})$ and $\mathrm{C}$ (MBC); Soil Basal Respiration (BRA), Total Organic Carbon (TOC), Total Nitrogen (TN) and Nutrient Balance Index (NBI)].

\begin{tabular}{lcc}
\hline Parameters & Macadamia & Pomelo \\
\hline SPO & $* *$ & $*$ \\
COL & $* *$ & $*$ \\
MBC & $* \star$ & $*$ \\
MBN & $* *$ & n.s. \\
BRA & $*$ & $*$ \\
TOC & $* *$ & $* *$ \\
TN & n.s. & $*$ \\
NBI & n.s. & $*$ \\
\hline${ }^{*} F$ Significant at $p<0.05 ;{ }^{*}$ Significant at $p<0.01 ;$ n.s. $=$ Not significant.
\end{tabular}

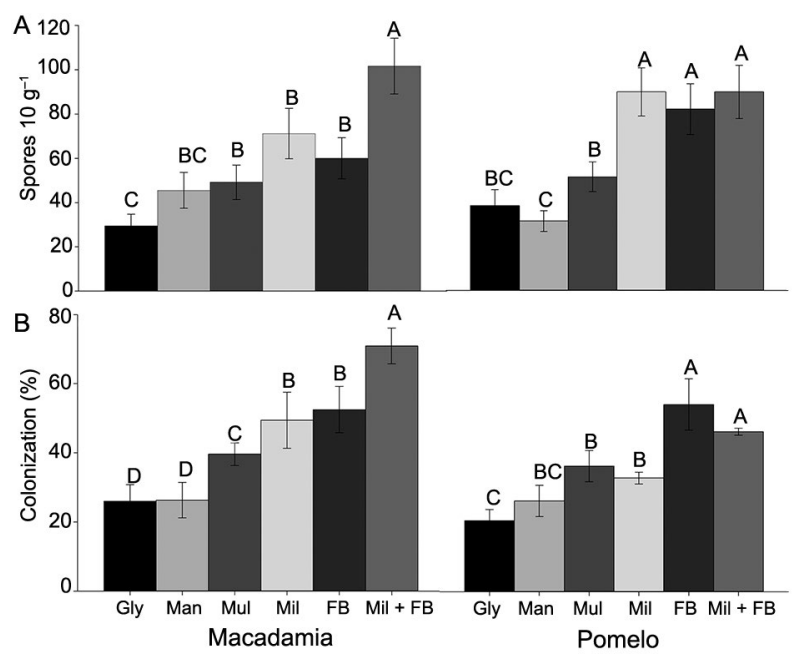

Figure 1 - A) Effects of cover crops (Gly = glyphosate; Man = manual; $\mathrm{Mul}=$ mulching; Mil = millet; $\mathrm{FB}=$ faba bean) on sporulation of Arbuscular Mycorrhizal Fungi (AMF) in macadamia and pomelo. B) Effects of cover crops on AMF colonization of macadamia and pomelo. Means followed by the same letters within each orchard fruit is not significantly different (Tukey test, $p \leq 0.05$ ). fruit orchards (Figure 2A). Moreover, the combination of cover crops and mulching improved MBC in both fruit orchards (Figure 2B), whereas MBN was significantly improved by mulching and other cover crop treatments in macadamia orchards (Figure 2C). For pomelo, no statistical difference was found for MBN.

Concerning the soil chemical properties, the levels of TOC in macadamia plots, mulching, and faba bean + millet had higher values than millet and faba bean, whereas in pomelo and macadamia, the herbicide plots had lower values than the other treatments (Figures 3A and B). However, TN was not altered by treatments, except in pomelo plots where only the mulching treatments kept the same concentration as herbicide. Overall, the effects of faba bean + millet were not so expressive on TOC, when comparing to other cover crops and mulching in both macadamia and pomelo orchards.

All parameters, which are indicators of soils microbial growth and activity, represented by MBC, MBN, COL and SPO, had a strong influence of mulching and faba bean + millet treatments as compared to manual and herbicide application.

Axis 1 from the PCA analysis demonstrated a strong contrast between these groups, where it was more remarkable in macadamia than in pomelo (Figure 4).

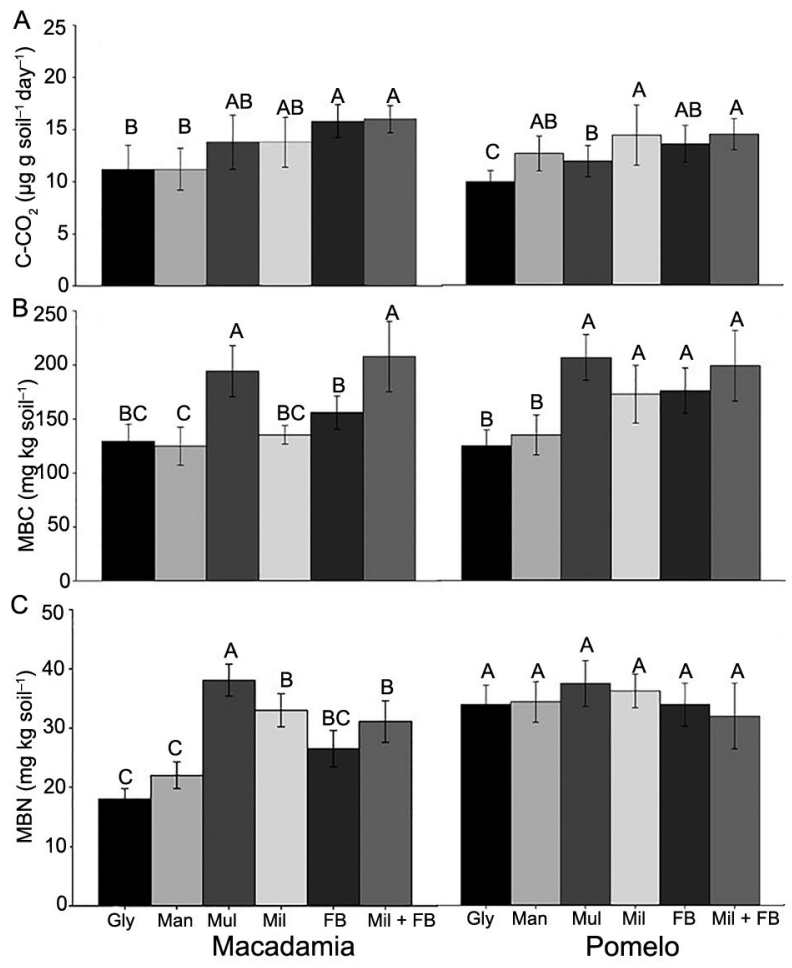

Figure 2 - A) Basal respiration in the soil with macadamia and pomelo with cover crops (Gly = glyphosate; $M a n=$ manual; $M u l=$ mulching; Mil = millet; $F B=$ faba bean). B) Effect on soil microbial biomass-C. C) Effect on soil microbial biomass-N. Means followed by the same letter within each orchard is not significantly different (Tukey test, $p \leq 0.05$ ). 


\section{Improved nutrient balance in fruit orchards}

The effects of cover crops on fruit orchard nutrition are presented in Table 3. The leaf analysis and calculation of the DRIS index for each macro and micronutrient were performed for macadamia and pomelo. Plant nutrients were more balanced under the faba bean + millet treatment. In pomelo orchards, the controls presented excess levels of $\mathrm{N}, \mathrm{Ca}, \mathrm{Mg}, \mathrm{Fe}$, and $\mathrm{Mn}$, and deficits of $\mathrm{P}, \mathrm{K}, \mathrm{S}$, and $\mathrm{Zn}$ compared with macadamia orchards. Despite these differences, cover crops consisting of faba bean alone or in combination with millet restored the concentrations of macro- and micro-nutrients (Table 3).

The correlation matrix for the DRIS rate of macadamia and pomelo (Table 4) showed that pomelo contains more correlated nutrients than macadamia. All elements, especially the $\mathrm{Zn}$ and $\mathrm{Mg}$, were found to have strong cor-

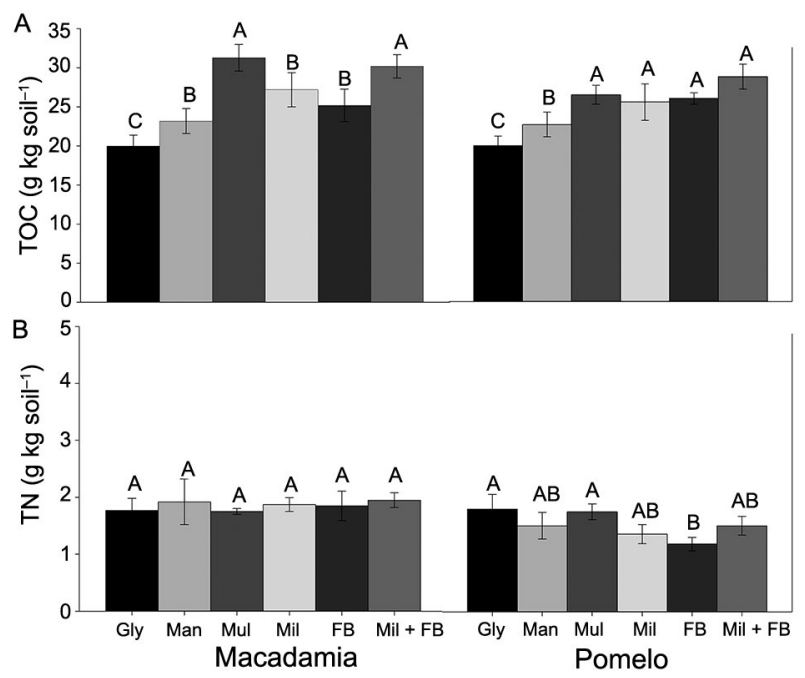

Figure 3 - A) Effects of cover crops (Gly = glyphosate; Man = manual; $\mathrm{Mul}=$ mulching; Mil = millet; $F B=$ faba bean) on soil total organic carbon in macadamia and pomelo. B) Effects of cover crop on soil total nitrogen. Means followed by the same letter within each orchard is not significantly different (Tukey test, $p \leq 0.05$ ). relations to other elements. In addition, $\mathrm{Ca}$ and $\mathrm{P}$ had many significant correlations. In macadamia, the highest positive correlations observed between nutrient levels included: $\mathrm{Ca} \times \mathrm{B}(0.71), \mathrm{Ca} \times \mathrm{Fe}(0.66), \mathrm{Ca} \times \mathrm{Mn}$ (0.82), $\mathrm{Cu}$ $\times \mathrm{Zn}(0.72)$, and $\mathrm{N} \times \mathrm{S}(0.67)$. However, in pomelo leaves, most correlations between nutrients levels were negative, and only a few existed for macadamia: $\mathrm{Cu} \times \mathrm{Mn}(-0.60)$, $\mathrm{Cu} \times \mathrm{Fe}(-0.59)$ and, $\mathrm{Cu} \times \mathrm{Ca}(-0.69)$.

The COL, SPO, BRA and TOC correlated negatively with NBI (Table 5) and MBN had some correlations with $\mathrm{P}$ and $\mathrm{B}$ concentration in plants. $\mathrm{TN}$ in the soil had the highest number of correlations with plant mineral nutrition data (Table 5). Considering the relationship between the soil data, COL and SPO were correlated to MBC and MBN, whereas TN had no relationship to other data (Table 6).

\section{Discussion}

In this study, cover crops reduced some negative effects on soils by benefiting the microorganism communities. Moreover, cover crops increased the num-
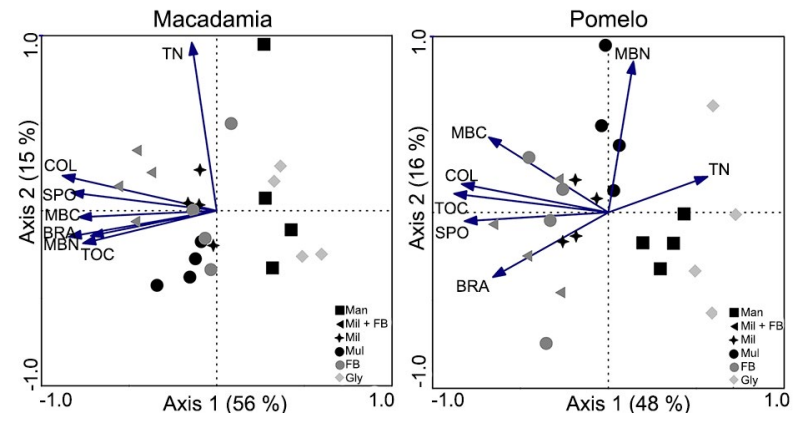

Figure 4 - Ordination diagram representing the Principal Component Analysis (PCA) of soil cover crop systems (Gly = glyphosate; Man = manual; $\mathrm{Mul}=$ mulching; Mil = millet; $F B=$ faba bean), in orchards of macadamia and pomelo. ( $\mathrm{COL}=$ mycorrhiza colonization; SPO $=$ number of spores; $\mathrm{TOC}=$ total organic carbon; BRA $=$ basal respiration; $\mathrm{MBC}=$ microbial biomass carbon; $\mathrm{MBN}=$ microbial biomass nitrogen).

Table 3 - The primary DRIS index that determines the limiting sequence of nutrients in macadamia and pomelo treated with glyphosate, manual, mulching, millet, faba bean and millet+faba bean.

\begin{tabular}{|c|c|c|c|c|c|c|c|c|c|c|c|c|}
\hline & & $\mathrm{N}$ & $\mathrm{P}$ & $\mathrm{K}$ & $\mathrm{Ca}$ & $\mathrm{Mg}$ & $S$ & $\mathrm{~B}$ & $\mathrm{Cu}$ & $\mathrm{Fe}$ & $\mathrm{Mn}$ & $\mathrm{Zn}$ \\
\hline \multirow{6}{*}{$\begin{array}{l}\frac{0}{d} \\
\text { Eั } \\
0\end{array}$} & Glyph. & 64.5 & -139.8 & -148.8 & 218.8 & 64.8 & -86.8 & -1.3 & 11.0 & 207.8 & 169.5 & -84.8 \\
\hline & Manual & 45.3 & -21.3 & 0.8 & 96.5 & -7.5 & 24.3 & -9.8 & 180.8 & 101.0 & 91.8 & -49.8 \\
\hline & Mulch. & 30.8 & -50.3 & -133.3 & 127.3 & 88.3 & -57.0 & 8.3 & -21.0 & 95.0 & 74.3 & 3.8 \\
\hline & Millet & -28.5 & 39.8 & 13.3 & -12.3 & -40.0 & 39.3 & 59.0 & 31.3 & 8.0 & -11.3 & -31.8 \\
\hline & Faba bean & -12.3 & 26.8 & 10.3 & -21.3 & -32.5 & 45.8 & 48.0 & 23.5 & -26.5 & -37.5 & 0.8 \\
\hline & Mil+Fab. & -0.3 & 2.5 & 1.8 & -3.3 & -0.5 & 1.0 & -1.0 & -0.5 & -3.3 & -1.8 & 1.5 \\
\hline \multirow{6}{*}{ 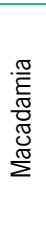 } & Glyph. & 2.8 & 8.5 & 14.0 & -7.5 & 0.0 & 7.3 & -3.3 & 15.3 & -10.0 & -13.0 & 17.0 \\
\hline & Manual & 24.5 & 34.3 & 39.3 & -55.0 & 11.8 & 31.3 & -56.3 & 49.3 & -51.3 & -52.8 & 34.0 \\
\hline & Mulch. & 20.3 & 15.8 & 17.8 & -11.0 & -0.5 & 27.3 & -10.8 & 11.0 & -19.0 & -16.0 & 6.3 \\
\hline & Millet & 4.5 & -0.3 & -6.5 & -3.5 & 11.3 & 6.3 & 4.5 & 1.0 & -5.5 & -3.5 & -3.5 \\
\hline & Faba bean & 5.3 & -3.5 & 8.8 & 12.0 & 1.8 & 13.0 & 7.5 & -12.0 & 3.8 & 8.3 & -9.8 \\
\hline & Mil+Fab. & -1.3 & -1.5 & -1.8 & 1.3 & 1.3 & -1.5 & 1.3 & -1.5 & 1.8 & 1.8 & -1.5 \\
\hline
\end{tabular}


Table 4 - Correlation matrix between the nutrient concentrations in macadamia and pomelo orchards treated with glyphosate, manual, mulching, millet, faba bean and millet+faba bean.

\begin{tabular}{|c|c|c|c|c|c|c|c|c|c|c|c|c|}
\hline & & $\mathrm{N}$ & $\mathrm{P}$ & K & $\mathrm{Ca}$ & $\mathrm{Mg}$ & $S$ & $B$ & $\mathrm{Cu}$ & $\mathrm{Fe}$ & $\mathrm{Mn}$ & $\mathrm{Zn}$ \\
\hline \multirow{11}{*}{$\begin{array}{l}\frac{0}{0} \\
\stackrel{\Xi}{0} \\
\text { ¿ }\end{array}$} & $\mathrm{N}$ & 1 & & & & & & & & & & \\
\hline & $P$ & -0.74 & 1 & & & & & & & & & \\
\hline & K & -0.65 & 0.88 & 1 & & & & & & & & \\
\hline & $\mathrm{Ca}$ & 0.82 & -0.96 & -0.87 & 1 & & & & & & & \\
\hline & $\mathrm{Mg}$ & 0.74 & -0.65 & -0.82 & 0.69 & 1 & & & & & & \\
\hline & $S$ & -0.74 & 0.69 & 0.83 & -0.68 & -0.93 & 1 & & & & & \\
\hline & B & -0.59 & 0.00 & 0.05 & -0.08 & -0.54 & 0.55 & 1 & & & & \\
\hline & $\mathrm{Cu}$ & 0.02 & 0.21 & 0.53 & -0.07 & -0.47 & 0.60 & 0.06 & 1 & & & \\
\hline & $\mathrm{Fe}$ & 0.81 & -0.94 & -0.79 & 0.98 & 0.61 & -0.62 & -0.08 & 0.04 & 1 & & \\
\hline & $\mathrm{Mn}$ & 0.90 & -0.89 & -0.74 & 0.95 & 0.69 & -0.69 & -0.30 & 0.06 & 0.97 & 1 & \\
\hline & $\mathrm{Zn}$ & -0.31 & 0.65 & 0.33 & -0.64 & 0.08 & 0.00 & -0.44 & -0.34 & -0.73 & -0.61 & 1 \\
\hline \multirow{11}{*}{ 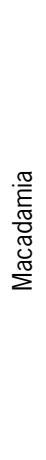 } & $\mathrm{N}$ & 1 & & & & & & & & & & \\
\hline & P & 0.47 & 1 & & & & & & & & & \\
\hline & K & 0.33 & 0.42 & 1 & & & & & & & & \\
\hline & $\mathrm{Ca}$ & -0.39 & -0.41 & -0.15 & 1 & & & & & & & \\
\hline & $\mathrm{Mg}$ & -0.06 & -0.18 & -0.08 & -0.09 & 1 & & & & & & \\
\hline & $S$ & 0.67 & 0.45 & 0.46 & -0.19 & 0.14 & 1 & & & & & \\
\hline & B & -0.27 & -0.41 & -0.25 & 0.71 & 0.13 & -0.20 & 1 & & & & \\
\hline & $\mathrm{Cu}$ & 0.31 & 0.57 & 0.29 & -0.69 & -0.09 & 0.24 & -0.54 & 1 & & & \\
\hline & $\mathrm{Fe}$ & -0.32 & -0.45 & -0.13 & 0.66 & 0.12 & -0.32 & 0.61 & -0.59 & 1 & & \\
\hline & $\mathrm{Mn}$ & -0.46 & -0.48 & -0.38 & 0.82 & 0.00 & -0.25 & 0.65 & -0.60 & 0.56 & 1 & \\
\hline & $\mathrm{Zn}$ & 0.11 & 0.53 & 0.48 & -0.35 & -0.19 & 0.15 & -0.30 & 0.72 & -0.31 & -0.41 & 1 \\
\hline
\end{tabular}

Table 5 - Correlations between the nutrient concentrations in leaves of macadamia and pomelo, Nutrient Balance Index (NBI) and other soil microbial and chemical data [AMF sporulation (SPO), and colonization (COL); Soil Microbial Biomass N (MBN) and C (MBC); Soil Basal Respiration (BRA), Total Organic Carbon (TOC) and Total Nitrogen (TN)].

\begin{tabular}{lccccccccccccc}
\hline & $\mathrm{N}$ & $\mathrm{P}$ & $\mathrm{K}$ & $\mathrm{Ca}$ & $\mathrm{Mg}$ & $\mathrm{S}$ & $\mathrm{Fe}$ & $\mathrm{Mn}$ & $\mathrm{Cu}$ & $\mathrm{Zn}$ & $\mathrm{B}$ & $\mathrm{NBI}$ \\
\hline SPO & 0.10 & 0.24 & 0.21 & -0.03 & 0.11 & 0.26 & -0.08 & -0.12 & -0.11 & 0.14 & 0.26 & $-0.30^{*}$ \\
COL & 0.00 & 0.04 & 0.03 & -0.12 & 0.01 & 0.05 & -0.17 & -0.04 & -0.16 & 0.08 & 0.13 & $-0.29^{*}$ \\
BRA & 0.04 & 0.11 & 0.09 & -0.11 & -0.03 & 0.09 & -0.07 & -0.01 & -0.04 & 0.03 & 0.09 & $-0.36^{*}$ \\
MBC & 0.18 & 0.28 & 0.18 & 0.01 & 0.19 & 0.23 & -0.17 & -0.19 & -0.04 & 0.22 & 0.17 & -0.19 \\
MBN & 0.23 & 0.18 & 0.09 & 0.16 & 0.20 & 0.15 & 0.11 & -0.16 & 0.03 & 0.09 & 0.157 & 0.04 \\
TOC & 0.85 & 0.13 & 0.07 & -0.07 & 0.07 & 0.14 & -0.20 & -0.10 & -0.18 & 0.09 & 0.10 & $-0.30^{*}$ \\
TN & $-0.43^{* *}$ & $-0.51^{* *}$ & $-0.54^{* *}$ & $-0.37^{* *}$ & $-0.38^{* *}$ & $-0.53^{* *}$ & 0.21 & $0.35^{*}$ & -0.22 & $-0.49^{* *}$ & $-0.55^{* *}$ & 0.15 \\
\hline
\end{tabular}

${ }^{*}$ Significant at $p<0.05 ;{ }^{* *}$ Significant at $p<0.01$.

Table 6 - Correlations between the soil microbial and chemical data [AMF sporulation (SPO), and colonization (COL); Soil Microbial Biomass N (MBN) and C (MBC); Soil Basal Respiration (BRA), Total Organic Carbon (TOC) and Total Nitrogen (TN)].

\begin{tabular}{|c|c|c|c|c|c|c|c|}
\hline & SPO & $\mathrm{COL}$ & BRA & MBC & MBN & TOC & TN \\
\hline SPO & 1 & $0.73^{* *}$ & $0.47^{* *}$ & $0.52^{* *}$ & 0.25 & $0.61^{*}$ & -0.24 \\
\hline $\mathrm{COL}$ & & 1 & $0.52^{* *}$ & $0.57^{* *}$ & $0.33^{*}$ & $0.62^{* *}$ & -0.17 \\
\hline BRA & & & 1 & $0.38^{* *}$ & 0.19 & $0.51^{*}$ & -0.20 \\
\hline MBC & & & & 1 & $0.39^{* *}$ & $0.63^{* *}$ & -0.10 \\
\hline MBN & & & & & 1 & $0.53^{* *}$ & -0.06 \\
\hline TOC & & & & & & 1 & -0.17 \\
\hline Total N & & & & & & & 1 \\
\hline
\end{tabular}

ber of spores and improved basic parameters of soil used for fruit orchards over a short-term period. The possible negative impact of herbicide was confirmed by the soil microbial growth results, whereas manual weed control and mulching treatments did not lead to significant improvements. Glyphosate is known to affect microorganisms, including the reduction of mycorrhizal colonization and growth of both target and non-target grasses by $23 \%$ and by around $44 \%$ arbuscules (Helander et al., 2018). Soil chemical characteristics may change the soil biological activity when herbicide, such as the glyphosate, is added, especially soil microbial biomass and soil respiration (Sumalan et al., 2010). 
Bacterial, fungal, and actinomycete populations, percentage of organic matter, and dehydrogenase activity all decreased upon treatment with herbicides in cassava fields (Sebiomo et al., 2011). Even though the beneficial effects of mulching in the soil, such as reduction of temperature ranging, erosion protection, ameliorate water preservation in dry areas and weed control (Oliveira et al., 2002), in our case, there was no response on soil microbial growth. Perhaps, the direct effect might be detectable in the long term, after years of cultivation with the same system.

Corroborating with the current results, cover crops benefit fruit orchards by improving soil microbial growth and activity, and different fruit orchards intercropped with cover crops can alter the rhizosphere microbial community (Manici et al., 2015).

Physical, chemical, and biological factors lead to nutrient depletion in the soil and reduced productivity because of conventional management and intensive use of pesticides, herbicides, and chemical fertilization (Tilman et al., 2002). Therefore, microbial biomass and AMF colonization could be used as indicators of soil quality (Vasconcellos et al., 2016).

In this study, both cover crops had positive effects on soil microbial quality for at least 120 days. Possibly, natural soil microbial communities are sensitive to cover crops, as they provide a variety of organic compounds that are released from the roots into the soil. In this sense, the combination of millet + faba bean and mulching was favorable to improve microbial growth, as indicated by the microbial biomass and BRA in the soil. Carbon root exudates released from grasses are estimated at $1.2 \mathrm{t} \mathrm{ha}^{-1}$ per year (Pausch and Kuzyakov, 2018), which can contribute to increase C content in the soil. In addition, faba bean can fix $\mathrm{N}_{2}$ from 100 to $200 \mathrm{~kg} \mathrm{~N} \mathrm{ha}^{-1}$ (Jensen et al., 2010) and legume plants can transfer $\mathrm{N}$ to grasses through their root system (Meng et al., 2015). The combination of grasses and faba beans could increase soil respiration and MBC (Sharmistha and Marschner, 2016). Therefore, the use of grasses-leguminous plants as cover crops might increase $\mathrm{C}$ and $\mathrm{N}$ input into the soils, crucial nutrient sources for the microorganisms.

In fact, some desirable attributes for soil evaluation are sensitive to short-term changes in soil, such as the soil microbial activities, represented by enzyme activities, which are more sensitive to green manure than to other chemical properties (Biederbeck et al., 2005). Moreover, biochar with rice husk and palm kernel could improve MBC and MBN, $\beta$-glucosidase and xylanase activities, thus this product might affect the microbial community by increasing active carbon sources in the short-term (Simarani et al., 2018). Therefore, in the specific case of our experiment, the microbial analysis was more responsive in short-term application. We hypothesize that response on soil chemistry, plant mineral nutrition and productivity might occur in the long-term.
Cover crop [pearl millet (Pennisetum glaucum) and jack bean (Canavalia ensiformis)] cultivation increased labile $\mathrm{C}$, which can enhance soil microbial activity and nutrient absorption by citrus trees [Pera' orange (Citrus sinensis)] (Oliveira et al., 2017).

Interestingly, mulching and millet + faba bean affected microbial data (MBC, MBN, BRA, SPO), but it did not change nutrient concentration of fruit trees, especially macronutrients (data not shown). However, the DRIS index indicated better nutrient balance in fruit trees treated with millet + faba bean. This suggests that soil microorganisms may indirectly alter mineral uptake in fruit trees, which decreases the range between excess and deficiency of nutrients. The positive effect of mulching on DRIS indexes was found in cherries that presented lower unbalanced indexes and relatively higher yields (Mourão Filho, 2004).

When an ecosystem is well balanced, nutrients are channeled according to plant demands and consequently might reduce losses by leaching and volatilization (Rengel, 1999). Macadamia and pomelo plants showed different responses to control, manual, and mulching treatments, although they improved in a similar manner when treated with two cover crops.

\section{Conclusions}

The cover crop systems and mulching in macadamia and fruit orchards can benefit the soil microbial growth, basal respiration and mycorrhiza in soils. This effect was more expressive in macadamia than in pomelo. Moreover, the use of both millet and faba bean together could improve some microbial indicators in the soil.

\section{Acknowledgements}

This work was supported by Conselho Nacional de Desenvolvimento Científico e Tecnológico (CNPq). Thanks also to all staffs of the Estação Experimental Universidade de Brasília and those undergraduate students who helped at this experiment.

\section{Authors' Contributions}

Conceptualization: Cruz, A.F.; Ramos, M.L.G. Data aquisition: Pires, M.C.; Nascimento, L.K.B. Data analysis: Oliveira, S.A.; Blum, L.E.B. Design of methodology: Cruz, A.F.; Ramos, M.L.G. Writing and editing: Cruz, A.F.; Yamanishi, O.K.

\section{References}

Biederbeck, V.O.; Zentner, R.P.; Campbell, C.A. 2005. Soil microbial populations and activities as influenced by legume green fallow in a semiarid climate. Soil Biology and Biochemistry 37: 1775-1784. DOI: 10.1016/j.soilbio.2005.02.011 
Cruz, A.F.; Ishii, T.; Kadoya, K. 2000. Distribution of vesiculararbuscular mycorrhizal hyphae in the rhizospheres of trifoliate orange and bahia grass seedlings under an intercropping system. Japanese Society for Horticultural Science 69: 237-242. DOI:10.2503/jjshs.69.237

Cruz, A.F.; Ishii, T.; Matsumoto, I.; Kadoya, K. 2003. Evaluation of the mycelial network formed by arbuscular mycorrhizal hyphae in the rhizosphere of papaya and other plants under intercropping system. Brazilian Journal of Microbiology 34: 72-76.

Food Agricultural Organization [FAO]. 2013. FAOSTAT: Statistical Database. FAO, Rome, Italy. Available in: http://faostat3.fao.org/ home/E [Accessed Jan 1, 2016]

Haney, R.L.; Brinton, W.H.; Evans, E. 2008. Estimating soil carbon, nitrogen, and phosphorus mineralization from short-term carbon dioxide respiration. Communications in Soil Science and Plant Analysis 39: 2706-2720. DOI:10.1080/00103620802358862

Helander, M.; Saloniemi, I.; Omacini, M.; Druille, M.; Salminen, J.P.; Saikkonen, K. 2018. Decreases mycorrhizal colonization and affects plant-soil feedback. Science of the Total Environment 642: 285-291.

Jayme-Oliveira, A.; Ribeiro Júnior, W.Q.; Ramos, M.L.G.; Ziviani, A.C.; Jakelaitis, A. 2017. Amaranth, quinoa, and millet growth and development under different water regimes in the Brazilian Cerrado. Pesquisa Agropecuária Brasileira 52: 561-571.

Jensen, E.S.; Peoples, M.B.; Hauggaard-Nielsen, H. 2010. Faba bean in cropping systems. Field Crops Research 115: 203-216.

Lana, R.M.Q.; Oliveira, S.A.; Lana, A.M.Q.; Faria, M.V. 2010. Coffea arabica L. nutritional status survey based on DRIS, in the Upper Paranaíba region - Minas Gerais. Revista Brasileira de Ciência do Solo 34: 1147-1156 (in Portuguese, with abstract in English).

Malavolta, E.; Vitti, G.C.; Oliveira, S.A. 1997. Evaluation of Plant Nutritional Status: Principles and Applications = Avaliação do Estado Nutricional das Plantas: Princípios e Aplicações. Potafos, Piracicaba, SP, Brazil (in Portuguese).

Manici, L.M.; Kelderer, M.; Caputo, F.; Nicoletti, F.; De Luca Picione, F.; Topp, A.R. 2015. Impact of cover crop in pre-plant of apple orchards: relationship between crop health, root inhabiting fungi and rhizospheric bacteria. Canadian Journal of Plant Science 95: 947-958. DOI:10.4141/cjps-2015-013

Meng, L.; Zhang, A.; Wang, F.; Han, X.; Wang, D.; Li, S. 2015. Arbuscular mycorrhizal fungi and rhizobium facilitate nitrogen uptake and transfer in soybean/maize intercropping system. Frontiers in Plant Science 6: 339.

Mourão Filho, F.A.A. 2004. DRIS: concepts and applications on nutritional diagnosis in fruit crops. Scientia Agricola 61: 550560.

Oliveira, F.N.S.; Lima, A.A.C.; Aquino, A.R.L.; Maia, A.M.F. 2002. Influence of deadleaves on tropical fruits development. Embrapa Agroindústria Tropical. Fortaleza, CE, Brazil. (Documentos, 49) (in Portuguese).

Oliveira, S.A. 2002. Foliar analysis. p. 245-256. In: Sousa, D.M.G.; Lobato, E., eds. Cerrado: soil liming and fertilization. Embrapa Cerrados, Planaltina, DF, Brazil.

Oliveira, F.E.R.; Oliveira, J.M.; Xavier, F.A.S. 2016. Changes in soil organic carbon fractions in response to cover crops in an orange orchard. Revista Brasileria de Ciência do Solo 40: e0150105. DOI: 10.1590/18069657rbcs20150105
Pausch, J.; Kuzyakov, Y. 2018. Carbon input by roots into the soil: quantification of rhizodeposition from root to ecosystem scale. Global Change Biology 24: 1-12.

Pimentel, J.V.F.; Guerra, H.O.C. 2011. Irrigation, organic matter and mulching in production of the seedlings of "cumaru" (Amburana cearensis). Revista Brasileira de Engenharia Agrícola e Ambiental 15: 896-902 (in Portuguese, with abstract in English).

Rengel, Z. 1999. Mineral Nutrition of Crops: Fundamental Mechanisms and Implications. Food Products Press, New York, NY, USA.

Sebiomo, A.; Ogundero, V.W.; Bankole, S.A. 2011. Effect of four herbicides on microbial population, soil organic matter and dehydrogenase activity. African Journal of Biotechnology 10: 770-778.

Setyawan, E.K.D.; Gilkes, R.; Tongway, D. 2011. Nutrient cycling index in relation to organic matter and soil respiration of rehabilitated mine sites in Kelian. Journal of Tropical Soils 16: 219-223.

Sharmistha, P.A.L.; Marschner, P. 2016. Soil respiration, microbial biomass $\mathrm{C}$ and $\mathrm{N}$ availability in a sandy soil amended with clay and residue mixtures. Pedosphere 26: 643-651.

Simarani, K.; Azlan Halmi, M.F.; Abdullah, R. 2018. Short-term effects of biochar amendment on soil microbial community in humid tropics. Archives of Agronomy and Soil Science 64: 18471860. DOI: $10.1080 / 03650340.2018 .1464149$

Strydhorst, S.M.; King, J.R.; Lopetinsky, K.J.; Harker, K.N. 2008. Forage potential of intercropping barley with faba bean, lupin, or field pea. Agronomy Journal 100: 182-190. DOI:10.2134/ agrojnl2007.0197

Subhani, A.; El-ghamry, A.M.; Changyong, H.; Jianming, X. 2000. Effects of pesticides (herbicides) on soil microbial biomass: a review. Pakistan Journal of Biological Sciences 3: 705-709.

Sumalan, R.M.; Alexa, E.; Negrea, M.; Sumalan, R.L.; Doncean, A.; Pop, G. 2010. Effect of glyphosate on the microbial activity of two Romanian soils. Communications in Agricultural and Applied Biological Sciences 75: 167-172.

Tilman, D.; Cassman, K.G.; Matson, P.A.; Naylor, R.; Polasky, S. 2002. Agricultural sustainability and intensive production practices. Nature 418: 671-677.

Vance, E.D.; Brookes, P.C.; Jenkinson, D.S. 1987. Microbial biomass measurements in forest soils: the use of the chloroform fumigation-incubation method in strongly acid soils. Soil Biology and Biochemistry 19: 697-702. DOI: 10.1016/00380717(87)90051-4

Vasconcellos, R.L.F.; Bonfim, J.A.; Baretta, D.; Cardoso, E.J.B.N. 2016. Arbuscular mycorrhizal fungi and glomalin-related soil protein as potential indicators of soil quality in a recuperation gradient of the Atlantic Forest in Brazil. Land Degradation \& Development 27: 325-334. DOI: 10.1002/ldr.2228

Zaccheo, P.V.C.; Neves, C.S.V.J.; Mariano, D.C.; Zorzenoni, T.O.; Higashibara, L.R.; Piccinin, G.G.; Okumura, R.S. 2013. Green manure in fruticulture: aspects on soil quality and use in agriculture. African Journal of Agricultural Research 11: 14691474.

Zaller, J.G.; Heigl, F.; Ruess, L.; Grabmaier, A. 2014. Glyphosate herbicide affects belowground interactions between earthworms and symbiotic mycorrhizal fungi in a model ecosystem. Scientific Reports 4: 5634. 